\title{
«САМОСОБОЮНАПОВНЕННЯ» ВАСИЛЯ СТУСА В КОНТЕКСТІ ПРАКТИК ДУХОВНОГО ПЕРЕТВОРЕННЯ ЛЮДСТВА
}

У статті розглядасться «самособоюнаповнення» В. Стуса як поетичне кредо митчя й орихінальна філософія, що своїми джерелами має «філософію серия» Г. Сковороди, створення себе як «великої ентелехї̈ Й. В. Г'ете, обряди християнської інічіачії та східну філософію суфізму. Досліджується вираження чієї естетично-філософської позичії на тематичному, образно-символічному та лексичному рівнях збірки «Час творчості».

Ключові слова: «самособоюнаповнення», прафеномен, ентелехія, інічіація, закон полярності,філософський мазохізм, філософія суфізму.

В статье рассматривается «самособоюнаполнение» Василя Стуса как поэтическое кредо художника и оригинальная философия, которая своими источниками имеет «философию сердиа» Г. Сковороды, сотворение себя как «великой энтелехии» И. В. Гете, обряды христианской инициачии, восточную философию суфизма. Исследуется выражение этой философской позиции на тематическом, образно-символическом и лексическом уровнях сборника «Время творчества».

Ключевые слова: «самособоюнаполнение», иничиачи, энтелехия, прафеномен, закон полярности, философия суфизма, философский мазохизм. 
In the article deals with the "self-fulfillment" by Vasyl Stus as his poetical credo. His original philosophy comes out of "the philosophy of the heart" by Grygoriy Skovoroda, the creation of the self as "great entelechies" by Johann Wolfgang von Goethe, Christian intitiation rituals and the eastern philosophy of sufism. The author researches the expression of this aethetical-philosophical position on the thematic, imagerial-symbolic and lexical levels of the collection of poems "Creativity Time".

Key words: "filling of yourself", "initiation", "Sufism", "entelechy", prafenomen, "the law of polarity", philosophical masochism.

Свою третю поетичну збірку «Час творчості» В. Стус створював 318 січня по 30 вересня 1972 року, перебуваючи під слідством у камері попереднього ув'язнення Київського КДБ. Тому настроєве iї тло визначила гірка іронія $з$ приводу щедрого дарунку долі: caмотності й великої кількості вільного часу - «ідеальних» умов для творчості. Попри цей тужливий настрій, поет зумів перетворити тюремний час на час сакральний, адже своє буття у світі виразив через сакральне світовідчуття, що є однією з наріжних естетичних категорій у світовій літературі.

Вияви універсальної категорії сакрального в художній прозі епох модернізму та постмодернізму найбільш грунтовно дослідив I. Набитович [Набитович 2008]. На думку дослідника, з крахом ідеології марксизму-ленінізму в материковій літературі релігійне відродження значно посилилося: «Сьогодні иіла плеяда мислителів намагається осмислити Бога, повернутись до якоїсь форми одкровення» [Набитович 2008: 126].

Нове духовне народження В. Стуса позначилось його зверненням до сакральних категорій та образів, що ставали єдиним порятунком в умовах ув'язнення, невизначеного майбутнього, коли одночасно переплелися всі «спроневіри» й переживання утрат з відроджуваними надіями зсередини створити себе і таким чином наголосити на цінності людського життя, знівельованого в часи тоталітаризму.

I. Набитович стверджує, що присутність сакрального в художньому творі обумовлена прагненням мистецького впорядку- 
вання позірного хаосу людського буття до певної системи [Набитович 2008: 266].

Віднайдене В. Стусом «самособоюнаповнення» стало і формою поетичного одкровення, і неоціненним духовним набутком, $\mathrm{i}$ засобом кшталтування духу, що допомагав пройти кола насильного відчуження від світу рідних, перейти межу на територію духовно посвяченого.

М. Коцюбинська розглядає Стусове «самособоюнаповнення» в трьох духовних вимірах: по-перше, як alter ego поезії митця, «ï̈ передумова й мета, виправдання їі існування $і$ неминуща суть» [Коцюбинська 2004: 153]; по-друге, як позицію внутрішньої свободи, звільнення від себе [Коцюбинська 2004: 157]; по-третє, як цілісність, неперервність духовного розвитку, культури [Коцюбинська 2004: 162].

Визнаючи слушність цієї концепції, ми спробуємо розширити іï межі дослідженням тих філософських джерел, що лягли в основу практики духовного пересотворення українського поета.

Досліджуючи психотип українського філософа, Н. Зборовська в монографії «Код української літератури» наводить міркування Платона про те, що «філософи справді прагнуть померти», тобто очиститися, визволитися «від нерозважливого впливу тіла» $\mathrm{i}$ пізнати чистоту, якою є трансцендентна істина [Зборовська 2006: 80]. На думку дослідниці, цей психотип українського філософа «вивершив у "старосвічькій" літературі Г. Сковорода, згодом поезії Т. Шевченко, у XX cm. він дзеркально відобразиться в екзистенційному виборі В. Стуса» [Зборовська 2006: 80-81].

Обираючи психоаналіз одним з методологічних ключів до творчості В. Стуса, ставимо завдання з'ясувати, як у ліриці поета відобразилась позиція філософського мазохіста і репрезентувався через реалізацію коду батьківства мужній український психотип.

Читачеві важко дається відчитування світових духовних практик у творчості українського поета, адже, як справедливо твердить Д. Стус, В. Стус говорив «з великими - Г'ете, Рільке, Пасте- 
рнаком - ніби на рівних: бо й вони, $і$ він уже з того боку, за гранню буденного життя людини» [Стус 2004: 253], а за цією межею «поезія перестає бути штукою, а стає сакрумом» [Стус 2004: 256]. К. Москалець бачить значення творчості Г'ете для Стуса в можливості викшталтувати власний дух [Москалець 1999: 226].

Український поет вдається до духовного досвіду людства. Ідея «самособоюнаповнення», що в умовах несвободи ставила на шлях самопізнання, була суголосна філософсько-естетичним шуканням улюблених Стусових мислителів Г. Сковороди та Й. В. Г'ете.

«Пізнай себе - створи себе - звільнись від спокус світу» стало апофеозом життя українського філософа, який у час народження Й. Г'ете вже був автором «філософії серця», покликаної зробити людину щасливою.

Й. Г’ете прийшов до свого нового дня народження в період веймарської класики. На цьому етапі він прагне підготувати себе як «ентелехію» і злитися зі світовою душею, тобто, згідно з ученням Спінози, здобути своїй душі безсмертя. На цьому шляху він ставив перед собою завдання пізнати самого себе, створити себе. Минуще більше не цікавило митця, він стояв на шляху пізнання незмінного. Керуючись внутрішнім імперативом «Я мушу стати сталим» [Шалагінов 2003: 148], Г’ете на свій дух накладав карб грунтовності.

Досвід духовного переродження великих особистостей людства надихнув Стуса. Працюючи над збіркою «Час творчості», він прагнув подібної сталості та грунтовності духу і, за словами К. Москальця, «явив у своїй творчості "зреформоване християнство ", яке узгоджувалось з його філософією вчинків та імперативом активного кшталтування самого себе і навколишнього світу» [Москалець 1999: 220].

До «самособоюнаповнення» як внутрішньої свободи поет іде через звільнення від тягаря буденності, від несвободи зовнішнього світу: «Яке блаженство - радісно себе / пуститися, неначе човен 
берега... / Як легко, збувшися старих вериг, почутись вільному, з собою в парі» [Стус 1995: 13].

Крім того, завжди близьким був Стусові образ «належної людини», що містить всю повноту буття, такий популярний у віршах Г’ете періоду його «штюрмерства». Цей образ у пізній творчості німецького поета знайшов своє втілення в ідеї «прафеномена», наділеного внутрішнім стремлінням до розвитку. На думку Г'ете, людина після смерті повертається у світ природи у вигляді безсмертної ентелехії [Шалагінов 2003: 171].

Найближчою українському поетові можна назвати думку Й. Г'ете про свободу людини, якої вона досягає через власний безперервний чин, викликаний не зовнішньою необхідністю, а внутрішніми вольовими імпульсами. Навіть утрачаючи зв'язок із зовнішнім світом, така людина здатна підносити свій дух, усвідомлюючи підвладність собі свого внутрішнього світу. У площині віднайдення рівноваги між зовнішнім світом, що ставить людині щораз нові перешкоди, та повнотою діяльного духовного існування індивіда полягає суть діалогу між двома великими поетами.

Універсальний символізм збірки «Час творчості» виявляе спільність світогляду автора зі світоглядом барокової людини, зокрема й у відчутті антитетичної природи буття. В. Стус свій життєвий період 3 початку ув'язнення сприймає одночасно як час утрат і час набутків. Текст вірша «Блажен, хто тратити уміє...» [Стус 1995: 19] є реалізацією авторської концепції мистецтва - як sacrum. Поет переживає одкровення про своє містичне покликання творити, ніби брати участь у релігійному досвіді. Усвідомлюючи це покликання, він готується відбути ритуали утрат усього, що важило в земному житті, і стати на новий шлях, згубний та рятівний водночас. Час на цій новій дорозі вже не спливає повільно, він асоціюється з безупинним летом, який щомиті наближає до кінця земного шляху. Тому так важливо встигнути порятувати свою поетичну суть, як Сковорода рятував серце, офіруючи йому свою плоть. Цей процес утрати себе як земного чоловіка й перехід у 
новий статус духовно посвяченого $є$ одним із важливих аспектів Стусового «самособоюнаповнення»:

а все ж буття твоє - у леті,

і в ньому - порятунок твій.

Вся суть твоя - лише в поеті,

а решта - тільки перегній, що живить корінь.

В. Івашко називає в Стуса вражаючою «готовність переступити поріг смерті, зримувати зі смертю своє життя». У віршах поета критик бачить «зв 'язок між універсальною символікою, притаманною геройчному ліризму, та християнською парадигмою» [Івашко 1994: 118]. Ідеться про зміну в українській ментальності ставлення до смерті, у цьому ж одне з найважливіших значень віршів Стуса: «Майже два столітmя втечі од смерті розділяє добу бароко й поета, який підніс "мистецтво помирати" на небачену в сучасній європейській культурі висоту»" [Івашко 1994: 119].

У віршах збірки концепт смерті розгортається в дуалістичнометафізичному, узгодженому з християнською парадигмою, аспекті. У метафоричних асоціаціях поет бачить тюрму, камеру як «занадто творчу хату», бо тут творчість стала життям, а будні - святами. Тут під час творчості розкривається його оголене, беззахисне серце, яке принижують, обмацуючи руками та поглядами. Викликаючи 3 себе смирення, ліричний герой тамує гнів, бо передчуває близьку мить смерті як входження в благодать, як ласку Господню, що є глибоким сакральним досвідом людини і важливим етапом на шляху до духовного перетворення:

Не зважай на те, не сердься:

те одвічне, що над нами, стріли повиймає 3 рани 


\section{і губами обцілує -}

адже хвиля пожадана

убиваючи рятує.

(«Будні тут тобі про свята» [Стус 1995: 29])

Збірку «Час творчості» К. Москалець визначає найдивовижнішим і водночас непідробним явищем в усій новій українській літературі: «Людина, яка переживає таке тривале релігійне осяяння, з якою здійснюється Преображення і обожнення, описує иі події як щось природне, обходячись найпростішими символами, які давно стали загальниковими - хрест, страсна путь, небесний Отещь, небесна батьківщина тощо, роблячи своє письмо у кращих віршах збірки таким щільним і точним, що воно сприймається як іще нечувана добра вість» [Москалець 1999: 228].

Поет, проте, не обмежується міфологізацією власного життя. К. Москалець зауважує, що «сакралізачія побутових і родових зв 'язків поширюється згодом і на дружину Стуса» [Москалець 1999: 230].

Чоловічу тугу за втраченим щастям, що асоціюється з образом дружини, втілено у вірші «Ці яблука тримала у руках...» [Стус 1995: 26]. Яблука, передані в тюрму дружиною, так щемливоболяче нагадали про те, що «надто щирі були для нас минулих кілька літ». Ліричний герой, вочевидь, не народився аскетом. Він кохав і з примусу втратив, і тепер його стражданням нема «ні спину, ні обереги». І все ж саме дружині він звіряється у своїй, більшій, ніж до неї, любові «до мучених»:

$$
\begin{aligned}
& \text { до кожного, хто, запізнавши горя, } \\
& \text { віддарував мені, здається, вчора } \\
& \text { людську біду за декілька віків. }
\end{aligned}
$$

У вірші ніби палімпсестом прочитується християнська концепція образу Спасителя, що спокутує за людські гріхи. Цю модель-матрицю sacrum'y можна метафорично сприймати як згуще- 
ну енергію ірраціональних переживань поета. Корелятивна пара «поет - Христос» створюється за аналогією, яка полягає в походженні їх ініціаційної смерті, а також у розумінні семантики жертви: не Сина приносять у жертву, а він офірує себе сам.

К. Москалець називає достовірним Стусів досвід переіснування і пов'язує його з містичним досвідом орфіків: «В його камері взагалі нема книжок, за винятком Г'ете, чиї вірші він перекладає (серед иих віршів є $і$ "Праслова. Орфічне" - можливо, дороговказ, але не матеріал для запозичення)» [Москалець 1999: 228]. Так «Великі гімни» Г'ете складались під впливом творчості давньогрецького поета Піндара, що розвивав орфічне учення метемпсихозу - переселення душ. Орфіки вважали тіло тюрмою душі, у якій зосереджене божественне начало. Лише після смерті й багатьох перевтілень вона поверталася у свою природну стихію. Очевидно, що ідея «прафеномена» Г'ете має своїм джерелом містичне давньогрецьке віровчення.

Орфічна ідея подорожі душі в потойбічному царстві, де на неї чекає перевтілення задля народження в новому часі, узгоджується у віршах В. Стуса з ритуалами християнської ініціації:

$$
\begin{aligned}
& \text {...і навертається пора, } \\
& \text { коли, здається, все забуто, } \\
& \text { все пережито, все спливло, } \\
& \text { все виказано, перечуто, } \\
& \text { і зразу студиться чоло, } \\
& \text { і зразу грати почезають, } \\
& \text { і лють ховається у тінь. }
\end{aligned}
$$

Бо інші духи в нас вступають під знаком божих благостинь.

(«Оступить туга ненажерна...» [Стус 1995: 103])

Час переродження у вірші означено іменником «пора». Дієслівний ряд, вжитий у минулому часі, указує на розрив з минулим як перший етап ініціаційного переходу. Дієслова теперішнього 
часу свідчать про існування на межі: «студиться чоло» - приборкання пристрастей, що також може асоціюватися зі смертю; «грати почезають» - досягнення внутрішньої свободи; «лють ховається» примирення з долею, з утратами в передчутті Божої всеблагості. В останніх рядках вірша описано третій етап ініціаційного переходу реінкорпорацію - повернення уже в новій якості.

Вірші В. Стуса про шлях душі до безсмертя через самозречення відсилають як до християнських джерел, так і до духовної еволюції Г’ете, яка від початку була пов'язана з ідеями орфіків, пізніше - 3 підготовкою себе як ентелехії і завершилася творчою інтерпретацією в його «Західно-східному дивані» ідеї східного містицизму - суфізму «Вмри, щоб вічно жити!»

Можна спостерігати спільність ієрархічної стадіальності в пошуках істини старослов'янськими й християнськими неофітами та східними суфістами. В останніх перший ступінь осягнення істини іменувався «шаріат» і починався з природи. Другий - «тарикат»дарував «незрозуміле почуття», порив. Під час третього ступеня «хакихату» - індивід переживав стан найвищої одержимості, екстаз, що спонукав знехтувати обачністю, почуттям самозбереження. Четвертий ступінь - «маарифат» - вів до самознищення: смерті в полум'ї свічки, що має привести до відродження душі [Шалагінов 2003: 201-202].

Визначальний мотив смерті й відродження, відкидання світу 3 метою його наближення звучить у вірші Г’ете «Блаженна туга». Відмовившись від буденного, людина не втрачає світ, але здобуває його в новому, вищому вияві. Без цього нового смислу людина лише «похмурий прибулець» (ein traber Gast) [Шалагінов 2003: 202]. У віршах Стуса, як і у віршах пізнього Г’ете, звучить ідея возвеличення цінності життя як скінченного у нескінченному, а трагізм є рівновагою вищого пізнання.

Отже, збірка В. Стуса «Час творчості» являє собою міф про те, як життєвий час ув'язненого поета перетворюється на час священний, $є$ часом «відкуплення», воздається новим життям. Український поет вдається до духовного досвіду людства. Ідея «самосо- 
боюнаповнення», що в умовах несвободи ставила на шлях самопізнання, була суголосна філософсько-естетичним шуканням улюблених Стусових мислителів Г. Сковороди та Й. В. Г’ете.

Творчість Г'ете і Стуса споріднює засвоєне з античного мистецтва бажання вмістити у свої образи високе завдання для людини і в такий спосіб наблизити ії до божественного. У Г'ете можливості людського генія відображає «прафеноменальний» тип людини, стан одержимості творчістю, що дарує вічне життя. Щоб здобути своїй душі безсмертя, індивід мусить упродовж земного життя підготувати себе як ентелехію. Для цього необхідно:

- пізнати себе, зсередини створити себе;

- досягти внутрішньої свободи шляхом приборкання пристрастей;

- стати співтворцем природи, продовжуючи ії високі діяння в царині духовності.

Через успадкований з творчості Г’ете закон полярності, коли суть одного розкривається за допомогою іншого - протилежного, Стус продовжував розкривати антитетичну природу буття і розрив із зовнішнім світом компенсував «самособоюнаповненням»; страх смерті нейтралізував внутрішньою ідеальною суттю суб'єкта та його причетністю до Божої всеблагості, що виразив в оксимороні «життєсмерть»; осмислив свій час утрат як час набутків. Антиномічність як універсальність виражається й у ставленні Стуса до творчості, яку сприймав одночасно як дар, що зносить поета на Парнас, але й покару, що вимагає болючих утрат і відбирає життя.

Філософськими джерелами, що живили Стусів міф про шлях душі у безсмертя, можна назвати ритуали християнської ініціації, орфічні ідеї, давньогрецьку трагедію та міфологію, східний містицизм - суфізм. Більшість із них В. Стус у великій мірі засвоював 3 творів свого вчителя.

У Стусовому ліричному героєві прочитується образ г'етевських богорівних титанів та проблема героїзму. I хоч зовнішній світ завжди створює такому герою межі у вигляді демонічних трансцендентних сил («хвища», «злива» - у Стуса, буря (sturm) - у Г’ете), усе ж через напруження всіх душевних сил індивід засвідчує самоцінність внутрішнього буття людини. 


\section{БІБЛІОГРАФІЯ}

Зборовська 2006 - Зборовська Н. Код української літератури: Проект психоісторії новітньої української літератури : монографія / Н. Зборовська. - К. : Академвидав, 2006. - 504 с.

Івашко 1994 - Івашко В. Міф про Василя Стуса як дзеркало шістдесятників / В. Івашко // Світо - вид. - Липень - вересень 1994. - Число III (16). - С. 104-120.

Коцюбинська 2004 - Коцюбинська М. Поетове «самособоюнаповнення»: із роздумів над поезією і листами Василя Стуса // Коцюбинська М. Х. Мої обрії : в 2 т. / М. Коцюбинська. - Т. 2. - К. : Дух і літера, 2004. - 386 с.

Москалець 1999 - Москалець К. Страсті по вітчизні // Людина на крижині. Літературна критика та есеїстка / К. Москалець. - К. : Критика, 1999 - С. 209-254.

Набитович 2008 - Набитович I. Універсум sacrum'у в художній прозі (від Модернізму до Постмодернізму) : монографія / І. Набитович. - Дрогобич ; Люблін : Посвіт, 2008. - 600 с.

Стус 2004 - Стус Д. Василь Стус : життя як творчість / Д. Стус. -К. : Факт, 2004. - 368 с. Стус 1995 - Стус В. Твори : у 4 т. 6 кн. / В. Стус. - Т. 2 -Львів : Просвіта, 1995. - 429 с.

Шалагінов 2003 - Шалагінов Б. Шлях Г’ете: Життя. Філософія. Творчість : посібник для вчителя / Б. Шалагінов. - Харків : Веста ; Ранок, 2003. - 288 с. 